\title{
Eosinophilia and Hypereosinophilic Disorders - Update on Etiopathogeny, Classification and Clinical Approach
}

\author{
POLLIANA MIHAELA LERU ${ }^{1,2}$ \\ 1"Colentina" Clinical Hospital, Bucharest, Romania \\ ${ }^{2 ،}$ Carol Davila" University of Medicine and Pharmacy, Bucharest, Romania
}

\begin{abstract}
Eosinophils are innate immune leukocytes recruited in large numbers to sites of allergic inflammation and parasitic infections. Recent studies show additional pleiotropic effects of recruited eosinophils impacting immunomodulation, tissue homeostasis and repair. Pathologic conditions accompanied by blood eosinophilia are quite frequent in medical practice and may raise serious differential diagnosis problems in severe cases, that require a multidisciplinary approach. Hypereosinophilia may be reactive to other diseases or primary, representing hypereosinophilic syndromes, that are diagnosed based on clinical and laboratory criteria, according to actual international guidelines. The etiopathogenic diagnosis is difficult and delayed in many cases and clinical evolution may be severe, with multiorgan involvement and poor prognosis. Some cases remain idiopathic, despite exhaustive investigation. This paper aims to review the most recent data in the literature referring to the role of eosinophils in human pathology, diagnostic criteria and treatment strategies of hypereosinophilic syndromes, actual classification and to draw some useful recommendations in clinical practice.
\end{abstract}

Key words: eosinophils, hypereosinophilic syndromes, multidisciplinary approach.

\section{INTRODUCTION}

The eosinophilic leukocyte, which was discovered about 130 years ago and quickly associated with allergic and parasitic diseases, is still considered "an enigmatic and fascinating cell that has continued to intrigue biomedical scientists for more than a century" [1]. Eosinophils are bone marrow-derived, peripheral blood and tissue granulocytes, prominent in allergic and inflammatory responses against metazoan helminthic parasites, but rare in healthy individuals. Recent studies showed that eosinophils are recruited into tissues undergoing allergic reaction and for a time they might function as reparative cells to heal tissues injured during hypersensitivity reactions. Subsequent investigations revealed that eosinophils, particularly their granule proteins containing cationic toxins, have a striking ability to cause tissues damage and are also significantly more active in production of reactive oxygen species than the neutrophils [2]. Recognition of the phlogistic capabilities of the eosinophils has stimulated increased attention to eosinophilic diseases and to mechanisms by which these cells can damage tissues. Eosinophils are important inflammatory cells in asthma, allergic rhinitis and related diseases, eosinophilic gastrointestinal disorders, many other allergic conditions induced by food and drugs, parasitic infections and a broad spectrum of hypereosinophilic syndromes.

The International Cooperative Working Group on Eosinophil Disorders (ICOG-EO) was established in 2011 as an interdisciplinary network, including representatives from the fields of allergy, immunology, hematology, infectious diseases and molecular medicine. The ICON on Eosinophil Disorders was published in 2012 in World Allergy Organization Journal [3]. An update of World Health Organization on diagnosis, risk stratification and management of eosinophilic disorders was published in 2014, including a new classification of hypereosinophilic syndromes [4].

\section{EOSINOPHILS ORIGIN, REGULATION AND FUNCTIONS}

Eosinophils are terminally differentiated granulocytes that arise principally from the bone marrow, being more closely related to basophils than to neutrophils and monocytes, due to lineage differentiation at this stage. In addition, eosinophils retain elements of expression of basophil or mast cell- specific high-affinity Fce receptor, while basophils express small amounts of the eosinophil granule protein major basic protein (MBP ) [5]. 
The key cytokines that are critical for stimulation of bone marrow production of eosinophils include interleukines IL-3, IL-5 and granulocyte/macrophage colony-stimulating factor (GM-CSF). These three cytokines are also produced by $\mathrm{T}$ lymphocytes CD4 and CD8 from peripheral blood and inflammed tissues. It is well recognized that IL-5 is a key cytokine in terminal differentiation of eosinophils and it is a major therapeutic target for new medications to treat hypereosinophilic conditions. Eosinophils are predominantly tissue cells and their major target organ for homing in healthy individuals is the gastro-intestinal tract, possibly in response to environmental factors as part of the role in innate defense against parasites. In pathologic conditions, eosinophils may also home to other tissues, including lungs, skin and the brain (during stroke). Eosinophil number can remain high in the tissues even when peripheral numbers are low, suggesting that their survival is enhanced upon extravasation. Eosinophil is both a factory and a store for a large array of mediators, which are released upon activation and play an important role in various inflammatory reactions. It was shown that human eosinophils synthesize, store and release over 29 different cytokines, chemokines and growth factors. The lipid-derived mediators with profound biological activity are: leukotrienes, prostaglandins, thromboxane, lipoxines and PAF [6]. The crystalloid granule-derived cationic proteins are: major basic protein (MBP), eosinophil cationic protein (ECP), eosinophil peroxidase (EPO) and eosinophil-derived neurotoxin (EDN). Mechanisms associated with granule release in eosinophils are critical for the effector function of eosinophils. Without degranulation and mediator secretion, the eosinophil is a relatively inert cell and does not affect the surrounding tissues, as seen in cases of idiopathic pulmonary eosinophilia and eosinophilic pneumonia.

It is paradoxical that eosinophils, a Th2-type response marker cell type for allergic diseases or helminthic infections, generate both Th1 and Th2 cytokines [7].

Activated eosinophils have complex proinflammatory effects: direct cytotoxic against tissues and microorganisms, promote thrombosis, fibrosis and angiogenesis, tissue remodelling, platelet and endothelial cells activation.

The presence of eosinophils in the airways and gut mucosa has been associated with both IgEdependent (allergic) and IgE-independent (nonallergic) manifestations of disease.

\section{MECHANISMS OF HYPEREOSINOPHILIA}

The upper limit of normal for the range of $\%$ eosinophils in the peripheral blood is $3-5 \%$, with a corresponding absolute eosinophil count (AEC) of $350-500 / \mathrm{mmc}$. The severity of eosinophilia has been arbitrarily divided into mild (AEC from the upper limit of normal to $1500 / \mathrm{mmc})$, moderate $\left(\mathrm{AE}_{\mathrm{C}}\right.$ between $\left.1500-5000 / \mathrm{mmc}\right)$ and severe $(\mathrm{AEC}>$ $5000 / \mathrm{mmc}$ ) [8].

A number of immunologic and other pathologic conditions can cause reactive hypereosinophilia. These include: infectious diseases (helminth infections, HIV, certain fungi), allergic disorders (asthma, food and drug allergies, including DRESS syndrome, atopic dermatitis), chronic inflammatory and autoimmune diseases. Generally allergies are accompanied by mild to moderate hypereosinophilia, while parasitic infections may lead to severe hypereosinophilia. It is noteworthy that blood hypereosinophilia (HE) is not necessarily accompanied by organ damage (criteria for Hypereosinophilic syndrome HES not fulfilled), mostly when it is detected in early stages of disease. When a persistent hypereosino-philia is demonstrated in the absence of organ involvement or an underlying disease, the provisional diagnosis of $\mathrm{HE}$ of uncertain significance is established [9].

The degree and pattern of organ involvement in eosinophilic disorders are governed by two distinct factors: the increased production and/or persistent accumulation of normal or neoplastic eosinophils and persistent activation of eosinophils, which is responsible for the clinical manifestations of HES [10]. In many cases both eosinophilia and eosinophil activation are present and have similar underlying causes, but in other cases HE may persist for years without evidence of eosinophil activation or clinical manifestations.

The two principal pathogenic mechanisms that can trigger eosinophil growth and accumulation are either an intrinsic defect of eosinophil-committed neoplastic progenitor cells, caused by mutations including platelet-derived growth factor receptor (PDGFR) or fibroblast growth factor receptor 1 (FGFR1) or cytokines overproduction, such as IL-3 and IL-5 that stimulate the growth, differentiation and survival of eosinophils.

\section{HYPEREOSINOPHILIC SYNDROMES (HES)}

Hypereosinophilia (HE) has been defined as a peripheral blood eosinophil count greater than $1500 / \mathrm{mmc}$ and it may be associated with tissue 
damage. HE encompasses a broad range of nonhematologic (secondary or reactive, Table 1) and hematologic (primary, clonal) disorders with potential for end-organ damage. After exclusion of secondary causes, the classification of hypereosinophilic diseases is based on 2008 World Health Organization scheme of disease subtypes, including myeloid and lymphoid neoplasms with eosinophilia and abnormalities of PDGFRA, PDGRFB and FGFR1 [11]. In 2011, the Working Conference on Eosinophil Disorders and Syndromes proposed a new terminology for eosinophilic syndromes divided in: familial HE variant, $\mathrm{HE}$ of undetermined significance, primary (clonal/neoplastic) HE, and secondary (reactive) HE [12]. HES may be considered a provisional diagnosis until a primary or secondary cause of eosinophilia is recognized, while idiopathic HE is the preferred term when end-organ damage is absent. The diagnosis of idiopathic HE requires exclusion of all primary and secondary causes of hypereosinophilia, as well as lymphocyte-variant HE.
The modern definition of HES remains a vestige of the historical criteria outlined by Chusid et al. in 1975: blood hypereosinophilia over $1500 / \mathrm{mmc}$, persisting for at least 6 months, accompanied by one or more organs involvement and without evidence of any other cause of eosinophilia, such as allergies or parasitic infections [13]. The requirement that eosinophilia persists for more than 6 months is considered less consistent today, due to availability of more sophisticated tools for rapid evaluation and need for prompt treatment in order to minimize the end-organ damage.

Markers of hypereosinophilia progression are: serum concentration of cationic eosinophilic proteins (ECP, MBP, EPO, EDN), expression of surface activation markers, presence of abnormal genes (FIP1-L1, PDGFRA), serum tryptase concentration, presence of aberrant lymphocytes. Histopathologic examination of injured organs may confirm eosinophilic organopathy due to extensive deposition of cationic proteins, mainly MBP.

Table 1

Pathologic conditions associated with reactive hypereosinophilia [14]

\begin{tabular}{|l|l|l|}
\hline \multicolumn{1}{|c|}{ Reactive (HE r) } & \multicolumn{1}{|c|}{ Neoplasms } & \multicolumn{1}{c|}{ Rare diseases } \\
\hline $\begin{array}{l}\text { Allergic atopic or non-atopic diseases: } \\
\text { - bronchial asthma } \\
\text { - food allergies } \\
\text { - atopic dermatitis } \\
\text { - drug allergies (ex. DRESS syndrome) } \\
\text { - allergic broncho-pulmonary aspergillosis }\end{array}$ & $\begin{array}{l}\text { Hematologic neoplasms: } \\
\text { - myeloid: acute/chronic eosinophilic leukemia, } \\
\text { chronic myeloid leukemia Ph+, myelodysplastic } \\
\text { syndromes } \\
\text { - systemic mastocytosis, mast cell leukemia } \\
\text { - lymphoid: Hodgkin lymphoma, T cell lymphoma }\end{array}$ & $\begin{array}{l}\text { Churg -Strauss syndrome, } \\
\text { Gleich syndrome ( episodic } \\
\text { angioedema, eosinophilia, } \\
\text { polyclonal IgM ) }\end{array}$ \\
\hline $\begin{array}{l}\text { Infections: } \\
\text {-parasitic (Toxocara, Strongiloides, } \\
\text { Ascaridiasis, Trichinella, Echinococus, } \\
\text { scabies), fungal, viral (HIV, HCV) }\end{array}$ & $\begin{array}{l}\text { Solid neoplasms: adenocarcinoma of the lung, } \\
\text { gastro-intestinal tract, pancreas, thyroid, genital } \\
\text { and skin tumours }\end{array}$ & $\begin{array}{l}\text { Eosinophilia-Mialgia syndrome } \\
\text { Hyper - IgE syndrome } \\
\text { (immunodeficiency) }\end{array}$ \\
\hline Endocrine diseases (ex. Addison disease) & & Graft-versus-host disease \\
\hline $\begin{array}{l}\text { Autoimmune diseases (collagenosis), } \\
\text { other chronic inflammations }\end{array}$ & & \\
\hline
\end{tabular}

Primary HES (Table 2) was first described by Anderson and Hardy in 1968 as a severe disease characterized by fever, sweats, weight loss and cardiac failure accompanied by marked hypereosinophilia. Primary HES is a rare and severe disease, more frequent in men (sex ratio male/female = 9/1), with age onset between 20-50, clinically characterized by systemic symptoms such as fever, rash, asthenia, mialgia, cardiac failure and neurologic signs and symptoms, with high mortality.

Primary HES may be diagnosed (Figure 1) after exclusion of a reactive (secondary) hypereosinophilia and based on some distinct clinical and laboratory features, mainly the presence of fusion tyrosine kinase mutation FIP1L1/PDGFRA $(\mathrm{F} / \mathrm{P})$. The best described clinical subtypes are: myeloproliferative variant, associated with $\mathrm{F} / \mathrm{P}$ mutation and good response to imatinib and lymphoproliferative variant, generally responsive to corticotherapy or some steroid-sparing agents [12]. Despite comprehensive evaluation, about 50\% of patients cannot be classified in any of the two subtypes and can be included in three groups, based on clinical manifestations: benign (without evidence of end organ involvement), complex (with evidence of multisystem involvement) and episodic. 
Table 2

Primary HES variants

\begin{tabular}{|l|l|}
\hline Myeloproliferative (M-HES) & Lymphoproliferative (L-HES) \\
\hline - more aggressive clinical form & - increased production of eosinophilopoietic cytokines (IL-5) by \\
- male predominance & phenotypically abnormal clonal T cell in peripheral blood \\
- evidence of eosinophil-related tissue damage and tissue fibrosis & - increased serum IgE levels \\
(endomyocardial fibrosis, restrictive lung disease) & - equal frequency in men and women \\
- associate features of myeloproliferative disorders & - lower mortality \\
- presence of the fusion tyrosine kinase mutation FIP1L1/ & - gastro-intestinal symptoms and obstructive lung disease are \\
PDGFRA & common \\
- elevated serum tryptase levels & - risk of progression to lymphoma \\
- unresponsive to corticotherapy & - unresponsive to imatinib \\
- good response to imatinib therapy & - good response to corticosteroids \\
\hline
\end{tabular}

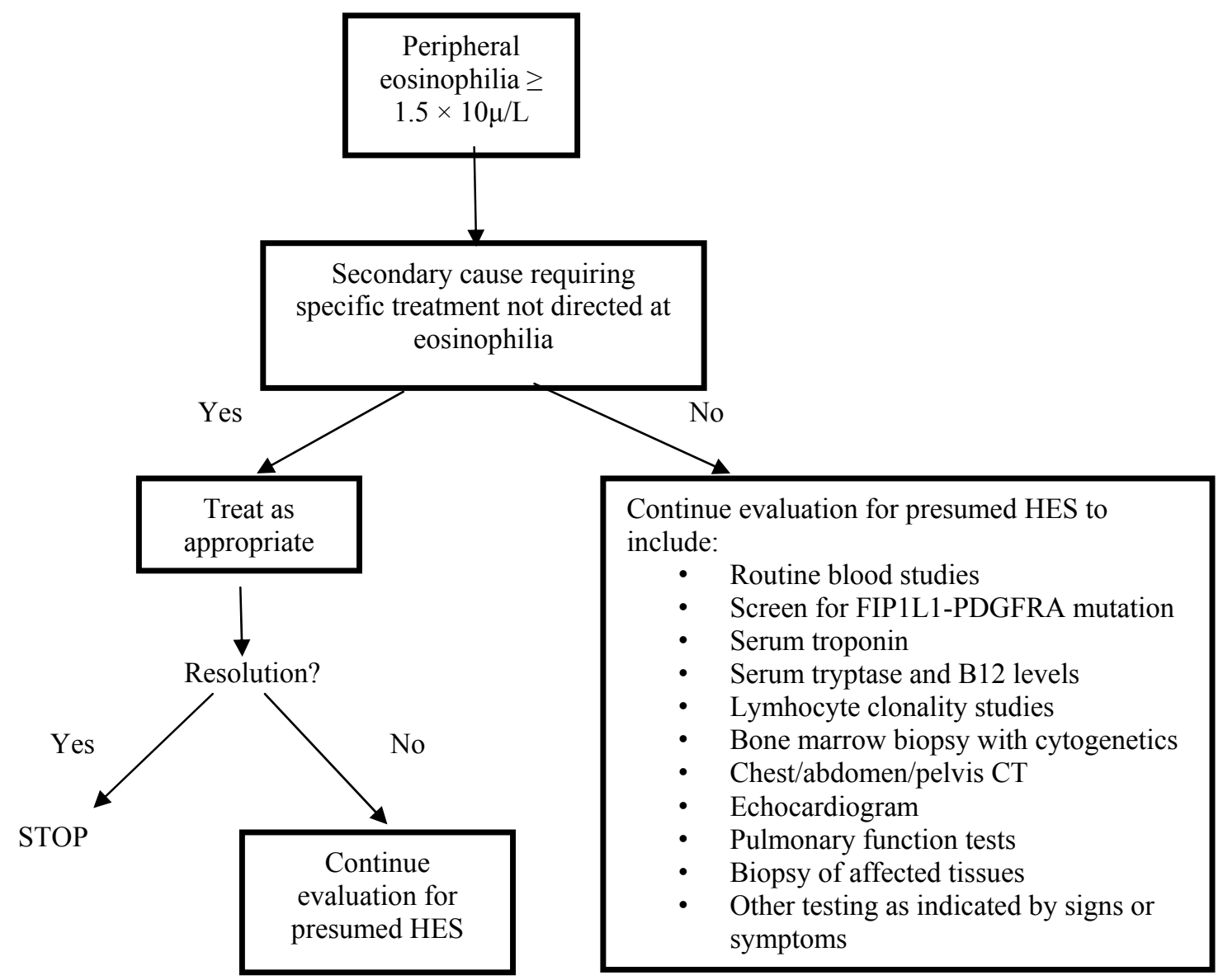

Figure 1. Diagnostic algorithm of HES (Adapted from Klion, Blood, 2009).

\section{HYPEREOSINOPHILIA \\ IN ALLERGIC DISEASES}

Allergic diseases are usually associated with mild to moderate blood hypereosinophilia $(<1500 /$ microL) and constant increase of activated eosinophils in affected tissues, mainly respiratory and gastro-intestinal tract. Due to continuous increasing prevalence of allergic diseases, arising to almost $30 \%$ from population in developed countries, mild to moderate hypereosinophilia is a current condition encountered in clinical practice. Eosinophilic diseases in this group include atopic and related diseases, such as allergic rhinitis, conjunctivitis, asthma, atopic dermatitis, some food allergies.

Drug allergies may be causes of more severe hypereosinophilia, one example being the Drug Rash with Eosinophilia and Systemic Symptoms Syndrome (DRESS). This is a severe hypersensivity reaction induced by drugs in most of the cases, 
with hypereosinophilia ( $>1500 /$ microL) and systemic symptoms, such as fever, rash, lymphadenomegaly and visceral involvement (myocarditis, hepatitis, nephritis, pneumonitis).

The most frequently used drugs that induce DRESS are: anticonvulsants (carbamazepine, valproic acid, phenitoin, lamotrigine ), sulphonamides, antifungal agents, NSAID, penicillins, quinolones, allopurinol, dapsone, spironolactone, calcium blockers.

The incidence of DRESS is $1 / 5000$ $1 / 10.000$ from patients exposed to anticonvulsants, the fatality risk is high - about $10 \%$ and the relapses and long term complications are possible.

Other severe diseases accompanied by marked hypereosinophilia are the two severe asthma phenotypes: Churg-Strauss syndrome (CSS) and allergic broncho-pulmonary aspergillosis (ABPA).

Churg - Strauss syndrome (CSS ) or the eosinophilic granulomatosis with polyangiitis (EGPA) is a severe asthma phenotype with systemic vasculitis and multiorgan involvement that is included in the group of antineutrophil cytoplasmic antibodies (ANCA) -associated vasculitis. The disease has three phases: the allergic phase, with asthma, rhino-sinusitis and nasal polyposis, the eosinophilic phase, with blood and tissues hypereosinophilia and a vasculitis phase, with fever, weight loss, pulmonary infiltrates, peripheric neuropathy, heart and renal manifestations [15]. Laboratory diagnosis is based on marked peripheral eosinophilia, inflammation markers, elevated serum IgE and IgG4 levels in most cases, ANCA perinuclear immunoflorescence pattern (P-ANCA) in $74-90 \%$ cases and histopathologic examination when possible.

Allergic broncho-pulmonary aspergillosis (ABPA) is a severe hypereosinophilic disease, induced by invasive and/or hypersensitisation to Aspergillus fumigatus, an ubiquitary fungus. Characteristic features of disease include: history of asthma, pulmonary infiltrates, mucoid impaction of the airways, peripheral eosinophilia, central bronchiectasis, elevated serum $\operatorname{IgE}$ and antiAspergillus specific IgG and IgE antibodies. The four major lesions of ABPA are asthmatic bronchiolitis, eosinophilic pneumonia, bronchocentric granulomatosis and mucoid impaction of the airways. The serologic diagnosis is very important especially when the diagnostic criteria are incomplete, to make the difference between asthma with allergic hypersensitisation to Aspergillus fumigatus, usually a mild disease and ABPA, which is a more severe form.

\section{HYPEREOSINOPHILIA IN PARASITIC INFECTIONS}

Infection with helminths is the most common cause of moderate to marked eosinophilia. Early studies demonstrated that eosinophils had the capacity to kill parasites, leading to the concept that eosinophils were immunoprotective. As in allergic inflammation, the role of esinophils in the immunopathological changes associated with helminth infections remains incompletely understood. The highest levels of blood hypereosinophilia are seen in tissue, long lasting parasitic infections with Toxocara canis or cati, Taenia, Echinococus, Trichinella spiralis and Strongiloides stercoralis.

Eosinophilic gastro-intestinal disorders (EGID) are characterized by eosinophilic infiltration of gastro-intestinal mucosa, with normal or elevated blood eosinophilia.

There are three types of eosinophilic diseases of the gastro-intestinal tract:

1. Gastro-intestinal diseases with eosinophilia (EGID): esophagitis, gastritis, gastro-enteritis, enteritis and colitis. The blood eosinophils number can be normal, endoscopically the mucosa can look normal or with patchy infiltrates, that need multiple sequential biopsies for diagnosis.

2. Gastro-intestinal eosinophilia in HES (usually accompanied by suggestive symptoms).

3. Reactive gastro-intestinal eosinophilia in: allergies, parasitic infections, cancers, etc. (associated with blood eosinophilia).

\section{PROGNOSIS OF HYPEREOSINOPHILIC SYNDROME}

Prognosis of HES is variable, depending on disease subtype, severity of hypereosinophilia and presence of organ damage, mainly early cardiac involvement.It is difficult to predict that duration and severity of eosinophilia will precipitate tissue damage in individual patients. The main factors predictive of a worse outcome are: the presence of a concurrent myeloproliferative syndrome, corticosteroid-refractory HE, cardiac disease, male sex and height of eosinophilia [16]. The cause of death, identified in a recent retrospective review, was: cardiac dysfunction, infection, unrelated malignancy, thrombo-embolic events and vascular disease [17].

\section{THERAPEUTIC CONSIDERATIONS IN HYPEREOSINOPHILIC DISORDERS}

Treatment of hypereosinophilia is based on identification and treatment of the causal disease first. Rapid institution of treatment is important to prevent irreversible organ damage, including endomyocardial fibrosis and thromboembolic events. 
The tyrosine-kinase inhibitor imatinib is the first line therapy in patients with FIP1L1 - PDGFRA positive disease and in rare patients with PDGFRA fusions or rearranged PDGFRB [18]. For patients with strictly defined HES (exclusion of all other possible causes of HE), corticosteroids are the mainstay of therapy, effective in producing rapid reduction of eosinophil count. The dose and duration of corticotherapy depend on severity of eosinophilia, individual response and presence of end-organ damage. Hydroxyurea is an effective first-line agent for HES which may be used in conjunction with corticosteroids or in steroid non-responders. Other therapeutic options are: anti IL-5 monoclonal antibodies (mepolizumab), Interferon-alfa, cyclophosphamide, leukapheresis, bone marrow transplantation, anticoagulants and antithrombotic agents.

\section{CONCLUSIONS}

Hypereosinophilic syndromes are clinical conditions that need interdisciplinary approach with many specialists, such as allergists, hematologist, internal medicine specialist, infectious diseases and clinical laboratory specialist. The main steps in clinical practice are: confirmation of hypereosinophilia, severity assessment, evaluation of organ involvement application of diagnostic algorithm, exclusion of the most frequent causes, such as allergies and parasitic infectious, adequate therapeutic strategy and close monitoring.

Conflict of interests: in relation with this paper the author declares that there are no conflicts of interest.

Eozinofilele sunt leucocite care intervin în răspunsurile imune înnăscute, fiind asociate în general cu inflamația alergică şi infecțiile parazitare. Studii recente evidențiază efecte pleiotrope adiționale ale eozinofilelor în procese imunomodulatoare, de homeostazie şi reparare tisulară. Afecțiunile însoțite de hipereozinofilie sunt relativ frecvente în practica medicală şi ridică adesea probleme de diagnostic diferential greu de rezolvat, care necesită o abordare multidisciplinară. Hipereozinofilia poate fi secundară, reactivă în cadrul altor boli sau primară, reprezentând sindroamele hipereozinofilice. Acestea sunt diagnosticate pe baza unor criterii clinice şi paraclinice definite, conform ghidurilor internaționale actuale. Diagnosticul etiologic este de multe ori dificil şi tardiv, iar evoluția poate fi severă, cu afectare multiorganică şi deces. Unele cazuri pot rămâne idiopatice, în ciuda investigațiilor exhaustive. Articolul de față îşi propune o evaluare a celor mai recente date din literatură privind rolul eozinofilelor în patologia umană, abordarea diagnostică şi terapeutică a sindroamelor hipereozinofilice şi unele considerații utile în practica medicală.

Correspondence to: Polliana Mihaela Leru, "Colentina" Clinical Hospital, Bucharest

E-mail: polianaleru@yahoo.com

\section{REFERENCES}

1. MOQBEL R, LACY P, ADAMKO DJ, ODEMUYIWA SO. Biology of Eosinophils. In Middleton's Allergy Principles and Practice, Seventh Edition. Cap 18, p. 295-310.

2. LACY P, MOQBEL R. Immune effector functions of eosinophils in allergic airway inflammation. Curr Opin Allergy Clin Immunol 2001; 1:79-84.

3. VALENT P, KLION AD, ROSENWASSER LJ, et al. ICON (International Consensus ON): Eosinophilic Disorders. Consensus document. WAO Journal 2012; 5:174-181.

4. GOTLIB J. World Health Organization - defined eosinophilic disorders: 2014 update on diagnosis, risk stratification and management. American Journal of Hematology 2014; 89(3):326-37.

5. GLEICH GJ. Mechanisms of eosinophil-associated inflammation. J Allergy Clin Immunol 2000; 105: 651-63.

6. HOGAN SP, ROSENBERG HF, MOQBEL R, et al. Eosinophils: biological properties and role in health and disease. Clin Exp Allergy 2008; 38:709-50.

7. WOERLY G, ROGER N, LOISEAU S, et al. Expression of CD28 and CD86 by human eosinophils and role in the secretion of type 1 cytokines (interleukin 2 and interferon gama: inhibition by immunoglobulin complexes. J Exp Med 1999; 190:487-495.

8. PARDANANI A, PATNAIK MM, TEFFERI A. Eosinophilia: Secondary, clonal and idiopathic. Br J Haematol 2006; 133:468-92.

9. GOTLIB J, COOLS J. Five years since the discovery of FIP1L1-PDGFRA: what we have learned about the fusion and other molecularly defined eosinophilias. Leukemia 2008; 22: 1999-2010. 
10. SIMON HU, ROTHENBERG ME, BOCHNER BS, et al. Refining the definition of hypereosinophilic syndrome. J Allergy Clin Immunol 2010; 126: 45-49.

11. BAIN BJ, GILLILAND DG, HORNY HP, et al. Myeloid and lymphoid neoplasms with eosinophilia and abnormalities of PDGFRA, PDGFRB or FGFR1. World Health Organization Classification of Tumors of Hematopoietic and Lymphoid Tissues. Lyon, France: IARC Press, 2008, p. 68-73.

12. VALENT P, KLION AD, HORNY HP, ROUFOSSE F, GOTLIB J, et al. Contemporary consensus proposal on criteria and classification of eosinophilic disorders and related syndromes. J Allergy Clin Immunol 2012; 130:607-612.

13. CHUSID MJ, DALE DC, WEST BC, WOLF SM. The hypereosinophilic syndrome: analysis of fourteen cases with review of the literature. Medicine 1975; 54: 1-27.

14. KLION AD. Recent advances in the diagnosis and treatment of hypereosinophilic syndromes. Hematology 2005; 209-14.

15. VAGLIO A, BUZIO C, ZWERINA J. Eosinophilic granulomatosis with polyangiitis (Churg - Strauss): state of the art. Allergy 2013; 68: 261-73.

16. LEFEBVRE C, BLETRY O, DEGOULET P, et al. Prognostic factors of hypereosinophilic syndrome. Study of 40 cases. Ann Med Interne (Paris) 1989; 140:253-7.

17. PODJASEK JC, BUTTERFIELD JH. Mortality in hypereosinophilic syndrome: 19 years of experience at Mayo Clinic with a review of the literature. Leuk Res 2013; 37:392-5.

18. KLION AD. How I treat hypereosinophilic syndromes. Blood 2009;114(18): 3736-41.

Received June 1, 2015 